\title{
Structure of Nursing Practice Implemented by Discharge Planning Nurses in Support During Transition to Homecare; Focus on Multidisciplinary Professional Case Conference Settings
}

\section{Mariko Zensho}

Department of Nursing, School of Health and Social Services, Saitama Prefectural University, 820 San-Nomiya Koshigaya-shi, Saitama, 3438540, Japan.

\author{
Article Details \\ Article Type: Research Article \\ Received date: $04^{\text {th }}$ November, 2019 \\ Accepted date: $23^{\text {rd }}$ November, 2019 \\ Published date: $25^{\text {th }}$ November, 2019
}

"Corresponding Author: Mariko Zensho, Department of Nursing, School of Health and Social Services, Saitama Prefectural University, 820 San-Nomiya Koshigaya-shi, Saitama, 343-8540, Japan. E-mail: zensho-mariko@spu.ac.jp

Citation: Zensho M (2019) Structure of nursing practice implemented by discharge planning nurses in support during transition to homecare; Focus on multidisciplinary professional case conference settings. J Comp Nurs Res Care 4: 154. doi: https:// doi.org/10.33790/jenrc1100154.

Copyright: $(02019$, This is an open-access article distributed under the terms of the Creative Commons Attribution License 4.0, which permits unrestricted use, distribution, and reproduction in any medium, provided the original author and source are credited.

\section{Abstract}

In order to organize the practices of hospital discharge planning nurses in the transition to homecare at a professional collaboration conference, 10 cases were surveyed, and were classified into 10 categories as a result of analysis by quoting GTA. They were: (1) Initial management of care-service planning by sharing issues associated with home-based care services. (2) Clarify the homebased care needs. (3) Detection of bewilderment in selection of care environment for families from complex patient/family backgrounds as well as their feeling of nursing burdens. (4) Extraction of multifaced issues associated with patients' self-care through demonstration of multidisciplinary expertness. (5) Sharing of patients' self-management methods associated with home-based drug therapy (6) Sharing issues for multidisciplinary collaboration/ cooperation along with feelings induced by expression of recognitions of patients and their families. (7) Planning of the home-based care support for the purpose of respite care. (8) Planning and assuring continuous provision of patient support through collaborations among individuals of the same profession in different divisions. (9) Encouragement of multidisciplinary participation in professional conferences supported by smooth collaboration among various professionals inside the hospital. (10) Reinforcement of their ability to identify characteristics of patients as local community members.

Keywords: Support During Transitional Home Care, Discharge Planning Nurse, Multidisciplinary Professional Case Conference

\section{Introduction}

\section{Background}

The core of the social security system shifted from income security to service security due to decreased family functions associated with increased medical. Nursing care needs and increase in number of nuclear families and elderly households (either single or married) are the consequence of super-aging and low birth-rate/high death-rate society in Japan.

As functional specialization, hospitals have been promoted in Japan for the purpose of reducing medical and nursing care expenses. Provision of decision-making supports through multidisciplinary collaboration/cooperationisnowessentialforpatientsandtheirfamilies so that they can choose the care environment and medical/nursing services that they receive when they discharged from the hospitals [1].

Meanwhile, "Law for Preparation of Relevant Laws to Promote Comprehensive Medical and Nursing Care Services in Local Communities" established in 2014 proposed a comprehensive community-based care system with which individuals can continue living as they want in the areas where they are used to live as much as possible until the end of life [2] and clarified the flow of promotion of home-based medical care [3].

In other words, it is considered that provision of adequate discharge supports through multidisciplinary collaboration/cooperation is crucial for patients with multiple medical/nursing care needs and their families, when they move from hospital-based care to homebased care.

As for the additional charge for discharge adjustment in 2008 Medical Fee Revision [4], it is now required to establish a dischargeadjustment section and to allocate nurses (specialized in discharge adjustment) and social workers who have adequate experiences in discharge adjustment to appropriate positions [5].

It is expected that medical expenses will be reduced by shortening the average length of hospital stay [6]. However, it has also been pointed out that early discharge may make it difficult for patients and their families to accept the reality and consider thoroughly how they are going to live afterward [7]; the role of nurses specialized in discharge adjustment who have adequate knowledge in medical and nursing care will become even more significant in the transitional support toward home-based care.

Preceding researches included many case studies on transitional supports toward home-based care.

These cases included a wide range of age groups with high-level and multiple medical care needs as well as long-term social support needs, [8-10] and the studies revealed that there were some issues such as inadequate assessment/planning supports from admission toward discharge and difficulties in reflecting patients/families' wishes as well as in holding and supporting multidisciplinary conferences on a regular basis [11].

According to the reports, it was suggested that the role of nurses specialized in discharge adjustment would be to encourage ward-based 
nurses to improve their abilities to support patient discharge, take leadership in consensus building in a team [12], establish a discharge-supporting system for the entire hospital, promote local collaborations, deal with ethical issues and to conduct selfmanagement, etc [13].

In overseas studies, following effects were observed with interventions with transitional supports toward home-based care.

An intervention with a discharge-support protocol "A New Multimodal Geriatric Discharge-Planning" significantly reduced the number of emergency outpatient visits and re-hospitalization rate [14].

"Family caregiver-oriented discharge planning program" for family caregivers of stroke patients significantly improved evaluations on interventions after hospital discharge made by the family caregivers compared to those before discharge, and significantly reduced the re-hospitalization rate in the follow-up investigation conducted one year later $[15,16]$.

According to evaluations made on outcome processes during the transitional phase toward home-based care in terms of provision of discharge support by emergency nurses, it was revealed that the intervention significantly helped them understand the management process of hospital discharge [17].

Provision of transitional supports toward home-based care by "The Geriatric Floating Interdisciplinary Transition Team" primarily involve nurses specialized in geriatric care may lead to reduction of the re-admission rate and medical expenses [18].

According to a literature review made by Norway and Dutch teams on qualitative and quantitative studies, it was suggested that further studies should be conducted in the future on use and development of social resources, health management of patients' families, multidisciplinary collaborations, and diversity of individual supports [19].

"Transitional Home Care Model (TCM)" designed by an academic team of Dr. Mary Naylor and researchers from the University of Pennsylvania proposed a system for the elderly patients with complex needs to deal with harmful effects, which commonly occur when moving from emergency medical setting to their homes or other medical facilities and to prepare themselves and their families to efficiently cope with health-status changes associated with multiple chronic diseases.

With regard to TCM, it was demonstrated that it would 1) avoid hospital re-admission due to primary diseases and complications, 2) improve health status of patients after hospital discharge, 3) improve care experiences of patients and family caregivers and reduce total medical expenses.

Moreover, it was revealed that the roles of "Transitional Home Care Nurses (TCM)" were to be a primary coordinator to coordinate potential and unexpected cares for acute diseases and to continue follow-up telephone consultations and home visits for at least two months after hospital discharge [20].

On the basis of the results obtained in the above-mentioned review, The author conducted this study in order to clarify the practice system for discharge planning nurses through reflections achieved immediately after multidisciplinary professional conferences, which provided the basis for directions regarding transitional supports toward home care and consensus building for patients with high medical-care needs who cannot be easily discharged and for their families.

\section{Objective}

The purpose of this study was to clarify the practice system for discharge planning nurses through reflections achieved after multidisciplinary professional conferences which provided the basisfor transitional supports toward home-based care for patients who cannot be easily discharged and for their families.

\section{Operational definitions of terms}

Transition toward home-based care

This indicates a period when a discharge planning nurse determines whether or not a patient needs to be discharged, introduces homebased care, and obtains a clear direction regarding stable use of social resources.

\section{Discharge planning nurse}

This indicates a nurse who has ability to find a factor which would make hospital discharge difficult soon after hospital admission and to provide supports so that the patient can be discharged at appropriate time to an appropriate place [21].

\section{Multidisciplinary professional conference}

This indicates a crucial support in the hospital discharge planning system where patients and their families as well as multidisciplinary professionals who are involved in decision making on transitional support toward home-based care meet each other, providing their skills and knowledge, and interact with each other to achieve the common goal, transition toward home-based care, through consensus building with the patients and their families so that they can determine directions in the support before discharge.

\section{Study design}

This is a qualitative descriptive study in which nursing phenomena of discharge planning nurses in multidisciplinary professional conferences were described in order to reveal the practice system.

In this study, we used Grounded Theory Approach (GTA) which is based on the theory of symbolic interactionism focusing on activities that take place between individuals.

Then, we attended multidisciplinary professional conferences and conducted group interviews which induced multidisciplinary reflections immediately after the conferences in order to reveal the practice system by observing each phenomenon from multiple perspectives, including how the discharge planning nurses behaved based on their implications of their practice and how they judged the necessity of transitional support toward home-based care through interactions with the patients and their families as well as other professionals to achieve directions.

\section{Study Method}

The study field was Hospital A, which is a primary local hospital of approximately 400 beds with 14 days of the average length of hospital stay, providing the secondary emergency medical services.

The staff members of the discharge planning section included 4 discharge planning nurses, 4 healthcare social workers, and 4 administrative workers. As for age of the discharge planning nurses, two were in late $40 \mathrm{~s}$, and one each in early $50 \mathrm{~s}$ and early $60 \mathrm{~s}$. For the number of years in nursing experiences, one was over 10 years, two over 25 years, and one over 40 years. The average number of years in discharge planning experiences was $4.3 \pm 3.0$ years. Two nurses were in manager positions.

\section{Subjects}

The investigational targets were 10 patients (cases) discussed in multidisciplinary professional conferences held between the end of March 2014 and the beginning of March 2015.

\section{Participants in the multidisciplinary professional conferences}

The number of eligible subjects was 80 , and the total was 91. The subjects included discharge planning nurses, patients, patients' families, family acquaintances, ward nurses, hospital doctors (physicians in charge), hospital pharmacists, hospital physiotherapists, hospital healthcare social workers, doctors in clinics, nursing care service specialists, home-visiting nurses, nursing care business owners, heads of day-care service centers, welfare and living environment business owners, and administrative officers (department of public assistance). 
The average number of participants was $9.1 \pm 2.9$, raged between 5 and 14. The overview of the cases are as follows: Aged between the late 40 s to late $80 \mathrm{~s}, 9$ males and 1 female, 2 singles, 6 married, 2 living in two-generation household, 1 requiring-help level 2, 1 long-term care level 1, 1 long-term care level 2, 1 long-term care level 3, 5 new applicants for nursing care insurance services, 1 dealt with medical insurance service, 3 public assistance recipients, and 3 emergency admissions.

\section{Subjects in the group interview surveys}

The number of eligible participants in the multidisciplinary professional conferences was 45 (participation rate $56.3 \%$ ), and the total was $54(59.3 \%)$.

The subjects included the participants from the conferences except for doctors and patients.

The average number of participants was $5.6 \pm 1.2$, raged between 4 and 7 . The overview of participants in the conferences and subjects in the group interview surveys is presented in Table 1.

\begin{tabular}{|c|c|c|c|c|c|c|c|}
\hline \multirow[b]{2}{*}{ case } & \multirow[b]{2}{*}{$\begin{array}{l}\mathrm{b} \text { a s i c a } 1 \\
\text { information. }\end{array}$} & \multirow[b]{2}{*}{ Diagnosis } & \multirow[b]{2}{*}{ participants } & \multicolumn{2}{|l|}{ conferences } & \multicolumn{2}{|c|}{ group interview surveys } \\
\hline & & & & $\begin{array}{l}\text { Number of } \\
\text { participants }\end{array}$ & $\begin{array}{l}\mathrm{T} \text { i } \mathrm{m} \mathrm{e} \\
\text { required } \\
\text { (min.) }\end{array}$ & $\begin{array}{l}\text { "Number of } \\
\text { participants } \\
\text { (Participation } \\
\text { rate\%)" }\end{array}$ & $\begin{array}{l}\mathrm{T} \text { i } \mathrm{m} \mathrm{e} \\
\text { required } \\
\text { (min.) }\end{array}$ \\
\hline 1 & $\begin{array}{lr}60 \mathrm{~s}, \text { male, } & \text { new } \\
\text { applicants } & \text { for } \\
\text { nursing } & \text { care } \\
\text { insurance services, } \\
\text { married }\end{array}$ & $\begin{array}{l}\text { "Churg Strauss } \\
\text { syndrome, Diabetes } \\
\text { mellitus, Dementia } \\
* \text { e m e r g e n c y } \\
\text { admission" }\end{array}$ & $\begin{array}{l}\text { "2discharge planning nurses, } \\
\text { hospital pharmacist,ward nurse, } \\
\text { hospital physiotherapists, } \\
\text { nursing care service specialist, } \\
\text { patients' family" }\end{array}$ & 7 & 52 & $5(71.4)$ & 30 \\
\hline 2 & $\begin{array}{l}70 \text { s, male, long- } \\
\text { term care level } 2, \\
\text { married }\end{array}$ & $\begin{array}{l}\text { "D e hy dration, } \\
\text { bruise, Chronic } \\
\text { bronchitis, Diabetes } \\
\text { * e m e r g e n c y } \\
\text { admission" }\end{array}$ & $\begin{array}{l}\text { "discharge planning nurse, } \\
\text { hospital doctors (physicians } \\
\text { in charge), ward nurse, } \\
\text { hospital physiotherapists, } \\
\text { medical social worker, } \\
\text { doctors in clinicsdoctors in } \\
\text { clinics, 2nursing care service } \\
\text { specialists, 2patients' families" }\end{array}$ & 10 & 81 & $5(50.0)$ & 36 \\
\hline 3 & $\begin{array}{l}\text { 60s,male, dealt } \\
\text { with medical } \\
\text { i n s u r a n c e } \\
\text { service, single, } \\
\text { public assistance } \\
\text { recipient }\end{array}$ & Diabetes mellitus & $\begin{array}{lr}\text { "discharge } & \text { planning } \\
\mathrm{n} \mathrm{u} \mathrm{r} \mathrm{s} \mathrm{e} \mathrm{,} \mathrm{h} \mathrm{o} \mathrm{s} \mathrm{p} \mathrm{i} \mathrm{t} \mathrm{a} 1 \\
\text { pharmacist,2ward } \\
\text { hospital physiotherapists, } \\
\text { home-visiting nurse, patient" }\end{array}$ & 7 & 31 & $4(57.1)$ & 27 \\
\hline 4 & $\begin{array}{lr}\text { 70s,male, new } \\
\text { applicants } \\
\text { nursing } \quad \text { for } \\
\text { insurance } \\
\text { married }\end{array}$ & $\begin{array}{l}\mathrm{D} \text { i a b e t i c } \\
\text { Nephropathy }\end{array}$ & $\begin{array}{l}\text { "discharge planning nurse, } \\
\text { hospitalpharmacist,ward nurse, } \\
\text { hospita physiotherapists, } \\
\text { home-visiting nurse,3welfare } \\
\text { and living environment } \\
\text { business owners, patient, } \\
\text { 2patients'families" }\end{array}$ & 12 & 37 & $7(58.3)$ & 23 \\
\hline 5 & $\begin{array}{l}\text { 70s,male, new } \\
\text { applicants for } \\
\text { nursing care } \\
\text { i n s u r a n c e } \\
\text { services, married, } \\
\text { public assistance } \\
\text { recipient }\end{array}$ & $\begin{array}{l}\text { Bowel obstruction, } \\
\text { Pneumothorax }\end{array}$ & $\begin{array}{l}2 \text { discharge planning } \\
\text { nurses, ward nurse, nursing care } \\
\text { service specialist, 2patients' } \\
\text { families }\end{array}$ & 6 & 47 & $6(100.0)$ & 39 \\
\hline 6 & \begin{tabular}{|lr}
$70 \mathrm{~s}$, male, & new \\
applicants & for \\
nursing & care \\
insurance & services, \\
married &
\end{tabular} & $\begin{array}{l}\text { Congestive heart } \\
\text { failure }\end{array}$ &  & 8 & 57 & $7(87.5)$ & 45 \\
\hline
\end{tabular}

Table. 1 to be Cont. 


\begin{tabular}{|c|c|c|c|c|c|c|c|}
\hline 7 & $\begin{array}{l}\text { 60s,male, long- } \\
\text { term care level } \\
1, \text { single, public } \\
\text { a s s i s t a n c e } \\
\text { recipient }\end{array}$ & $\begin{array}{l}\text { "P n e u m o n i a, } \\
\text { diabetes mellitus } \\
\text { * e m e r g e n c y } \\
\text { admission" }\end{array}$ & $\begin{array}{l}\text { discharge planning nurse, } \\
\text { hospital doctors (physicians } \\
\text { in charge),ward nurse, } \\
\text { nursing care } r \text { service } \\
\text { specialist,administrative } \\
\text { officers (department of public } \\
\text { assistance), patient }\end{array}$ & 6 & 87 & $4(66.7)$ & 20 \\
\hline 8 & $\begin{array}{l}40 \mathrm{~s}, \mathrm{~m} \text { a } 1 \mathrm{e}, \\
\text { requiring-help } \\
\text { level } 2 \text {, living in } \\
\text { two-generation } \\
\text { household }\end{array}$ & $\begin{array}{l}\text { A m y otrophic } \\
\text { lateral sclerosis }\end{array}$ & $\begin{array}{l}\text { discharge planning nurse, } \\
\text { hospital doctors (physicians in } \\
\text { charge), ward nurse, nursing } \\
\text { care service specialist,2home- } \\
\text { visiting nurses, living } \\
\text { environment business owner, } \\
\text { patient,6patients' families }\end{array}$ & 14 & 75 & $7(50.0)$ & 37 \\
\hline 9 & $\begin{array}{l}\text { 70s, femal,long- } \\
\text { term care level } \\
3, \text { living in } \\
\text { two-generation } \\
\text { household }\end{array}$ & $\begin{array}{l}\text { Diabetes mellitus, } \\
\text { Dementia }\end{array}$ & $\begin{array}{l}\text { discharge planning nurse, } \\
\text { hospital doctors (physicians } \\
\text { in charge),ward nurse, nursing } \\
\text { care service specialist, 2home- } \\
\text { visiting nurses,nursing care } \\
\text { business owners, heads of day- } \\
\text { care service centers, 3patients' } \\
\text { families,family acquaintance }\end{array}$ & 10 & 76 & $6(50.0)$ & 32 \\
\hline 10 & $\begin{array}{l}\text { 70s, male, new } \\
\text { applicants for } \\
\text { nursing care } \\
\text { insurance services, } \\
\text { married }\end{array}$ & $\begin{array}{l}\mathrm{P} \text { r o s t a t e } \\
\text { cancer, Stomach } \\
\text { ulcer }\end{array}$ & $\begin{array}{l}\text { discharge planning nurse, } \\
\text { hospital doctors (physicians } \\
\text { in charge),ward nurse, } \\
\text { hospital pharmacist, nursing } \\
\text { care service specialist, } \\
\text { home-visiting nurse,living } \\
\text { environment business owner, } \\
\text { patient,patients' family }\end{array}$ & 9 & 39 & $5(55.6)$ & 31 \\
\hline
\end{tabular}

Table. 1 The overview of participants in the conferences and subjects in the group interview surveys

\section{Data collection}

Out of all multidisciplinary professional conferences held by discharge planning nurses at Hospital A, we participated in each one of the conferences on 10 patients (cases) who submitted consent to participate in this study and conducted group interview surveys to induce reflections immediately after the conferences.

The average time required for each conference was $58.2 \pm 20.2$ minutes ranged between $31-87$ minutes.

During the interviews, we asked all the participants if they could adequately exchange opinions and collect information or how they understand the roles of discharge planning nurses in order to induce their self-reflections on the conferences as well as on practice of discharge planning nurses.

The average time required for the group interview surveys was 32.0 \pm 7.6 minutes ranged between 20 - 45 minutes.

Prior to the surveys, all participants agreed that we would record and take notes of the interviews and retain those as the original data.

\section{Data analysis}

GTA was applied in the process of qualitative data analyses for each one of the cases. In GTA, it is important to conduct theoretical samplings by simultaneous performing data collection, coding and analyses for each case, considering which data should be sampled next, and intentionally selecting the subjects and cases to obtain better data [22].

In this study, issues associated with diversity of subjects' characteristics and time restriction were expected in situations requiring cooperation from all the conference participants and in intentional case selection.

We therefore used GTA for analyses of individual cases, considering that there would be a limitation in theoretical samplings with strict continuous comparative analyses.

The analysis data included 10 cases/10 texts.

\section{The fist-stage coding}

We created a literal record for each case based on voice data and notes and analyzed 10 texts following GTA open coding. Each text was given I.D. numbers so that we would know who the speakers were and was divided into segments by meanings after grabbing the entire picture. Properties and dimensions were extracted from each segment of the text and labeled, and then the levels were grouped into categories and named based on the common features. Once the labels and categories were named, we had to confirm the compatibility between the text and the content.

\section{The second-stage coding}

For multidisciplinary reflections on practice of discharge planning nurses, we categorized them according to each phenomenon being evaluated.

We created a summary of each case by drawing a relationship chart in categories extracted from the first-stage coding. The categories were related to each other by properties and dimensions, and the main category which was selected out of all was named after the phenomenon.

Once all the category-relationship charts were obtained, we integrated the findings and created an integrated category-relationship chart on multiple phenomena.

\section{The third-stage coding}

We integrated categories to create a category-relationship chart and related them by properties and dimensions. Then we examined the main category and presented the practice system of discharge planning 
nurses in the transitional support toward home-based care in settings of multidisciplinary professional conferences using the integrated category-relationship chart and the summary. The main category [ ], categories $<>$, property “", dimension " .

\section{Quality assurance in qualitative data analyses}

In order to achieve reliability and reality in qualitative data, 4 discharge planning nurses and the author shared the analytical data of 10 cases. The author presented the data and analytical process to the qualitative researchers to obtain evaluations in the analyses.

\section{Ethical concerns}

This study was reviewed by the ethical committee of University B and approved by the dean of the university (No.25019). Following an advice from the chief nurse of Hospital A, the author submitted the study protocol and the study cooperation request form to the head of the hospital and the chief nurse and then obtained their consent for study cooperation before conducting the study.

Thereafter, the author explained the purpose and method of this study to the discharge planning nurses and obtained their consent for cooperation in the investigation.

The participants of multidisciplinary professional conferences (participants) individually received oral explanations on the purpose and method of this study by discharge planning nurses in advance and submitted the consent.

The author received information on multidisciplinary professional conference schedule from discharge planning nurses before participating in the conferences. He/she provided oral explanations to all the participants in advance using study instruction and informed consent forms. They participated in the conferences after submitting the consent.

Special attentions were paid to the information which might help others identify the individuals. Once consents were observed from the subjects, the author recorded the group interviews and produced literal records from the voice data.

The subjects were asked to confirm the data contents, and only the information approved by them were used as data. The recorded data were deleted after the author and the discharge planning nurses confirmed the literal records.

The multidisciplinary professional conferences were selected from general patient population regardless of their age, disease stage, and diagnosis.

For the patients and their families as well as the professionals were told that their hospital/home-based care lives or tasks would not be affected at all by whether or not they participate in this study. The contact information was provided so that the subjects could send inquiries, ask for advice, or withdraw consent.

\section{Results}

Ten categories extracted by analyzing individual cases and integrating the results are presented along with the details (Table 2).

\begin{tabular}{|c|c|c|c|c|c|}
\hline \multirow{2}{*}{ 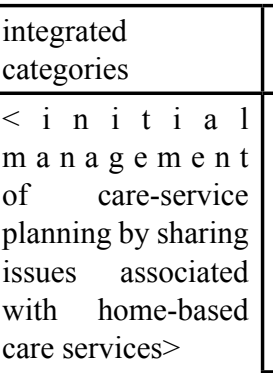 } & \multicolumn{5}{|c|}{ categoriesof each case } \\
\hline & $\begin{array}{l}<\text { coordination } \\
\text { of home support } \\
\text { services to support } \\
\text { family care and aLs } \\
\text { patients' desire to } \\
\text { recover their mind } \\
\text { and body }>\end{array}$ & $\begin{array}{l}<\text { introd ucing } \\
\text { home-visit nursing } \\
\text { services to support } \\
\text { medical care for } \\
\text { families> }\end{array}$ & $\begin{array}{l}<\text { adjustment of } \\
\text { home support } \\
\text { service according } \\
\text { to the family care } \\
\text { of aLs patients }>\end{array}$ &  & $\begin{array}{l}<\text { proposal of } \\
\text { support system for } \\
\text { insulin injection } \\
\text { management by } \\
\text { family members } \\
\text { and day service } \\
\text { nurses> }\end{array}$ \\
\hline & $\begin{array}{l}<\text { confirmation of } \\
\text { dialysis treatment } \\
\text { policy and hospital } \\
\text { location after } \\
\text { discharge }>\end{array}$ & $\begin{array}{lr}<\text { sharing } & \text { of } \\
\text { housing renovation } \\
\text { procedures } \\
\text { prevent falls }>\end{array}$ & $\begin{array}{lr}<\text { support } & \text { for } \\
\text { transportation } \\
\text { methods } & \text { with } \\
\text { heavy } & \text { physical } \\
\text { burden }> & \end{array}$ & $\begin{array}{l}<\mathrm{p} \mathrm{r} \text { o m o t } \mathrm{i} \text { o } \mathrm{n} \\
\text { of wheelchair } \\
\text { selection according } \\
\text { to individual needs } \\
\text { of aLs patients }>\end{array}$ & $\begin{array}{l}<\text { home support } \\
\text { service adjustment } \\
\text { related } \\
\text { improving to } \\
\text { lives of welfare } \\
\mathrm{r} \text { e c i p i e } \mathrm{n} \mathrm{t} s \\
\text { who repeat } \\
\text { hospitalization }>\end{array}$ \\
\hline & $\begin{array}{lr}<\text { promoting } & \text { the } \\
\text { awareness } & \text { of } \\
\text { individuals } & \text { living } \\
\text { alone }> & \end{array}$ & $\begin{array}{l}<\text { promotion of } \\
\text { life improvement } \\
\text { biased toward the } \\
\text { consumption of } \\
\text { luxury products> }\end{array}$ & $\begin{array}{l}<\text { e d u c a ti o n a l } \\
\text { intervention } r \text { to } \\
\text { improve family } \\
\text { care> }\end{array}$ & & \\
\hline \multirow[t]{2}{*}{$\begin{array}{l}<\text { clarify the home- } \\
\text { based care needs }>\end{array}$} & $\begin{array}{l}<\text { sharing diabetes } \\
\text { treatment policy of } \\
\text { physicians affected } \\
\text { by home support } \\
\text { system }>\end{array}$ & $\begin{array}{l}<\text { sharing of views } \\
\text { regarding the } \\
\text { causes of dyspnea } \\
\text { in patients by } \\
\text { the attending } \\
\text { physician> }\end{array}$ &  & $\begin{array}{l}<\text { problems in self- } \\
\text { management of } \\
\text { internal medicine } \\
\text { in single patients }>\end{array}$ & $\begin{array}{l}<\text { sharing the } \\
\text { current situation } \\
\text { that cannot support } \\
\text { attempts to eat } \\
\text { from the mouth } \\
\text { from the viewpoint } \\
\text { of hospital safety } \\
\text { management> }\end{array}$ \\
\hline & $\begin{array}{l}<\text { sharing problems } \\
\text { in home support } \\
\text { for severe care } \\
\text { recipients with } \\
\text { cognitive decline> }\end{array}$ & $\begin{array}{l}<\text { sharing problems } \\
\text { related to eating } \\
\text { habits of single } \\
\text { patients }>\end{array}$ & $\begin{array}{l}<\text { sharing home care } \\
\text { issues clarified by } \\
\text { overnight stay at } \\
\text { home> }\end{array}$ & & \\
\hline
\end{tabular}




\begin{tabular}{|c|c|c|c|c|c|}
\hline & $\begin{array}{l}<\text { sharing } \\
\text { walking assistance } \\
\text { to patients and } \\
\text { their families based } \\
\text { on the physical } \\
\text { fall } \\
\text { risk therapist } \\
\text { of assessment } \\
\text { occupations }>\end{array}$ & & & & \\
\hline & $\begin{array}{l}<\text { supporting the } \\
\text { needs for dialogue } \\
\text { with society }>\end{array}$ & \begin{tabular}{|lr}
$<$ sharing & negative \\
reactions & regarding \\
patient & home \\
support $>$ & \\
\end{tabular} & $\begin{array}{ll}<\mathrm{s} \text { h a } \mathrm{r} \text { i } \mathrm{n} & \mathrm{g} \\
\text { hospitalization } \\
\text { needs } & \text { and } \\
\text { dependence } & \text { on } \\
\text { hospitals } & \text { for } \\
\text { patients who are } \\
\text { accused of being } \\
\text { poor> }\end{array}$ & & \\
\hline $\begin{array}{lr}<\text { detection } & \text { of } \\
\text { bewilderment } & \text { in } \\
\text { selection of } & \text { care } \\
\text { environment for } & \\
\text { families rom } & \text { from } \\
\text { complex patient/ } \\
\text { family backgrounds } \\
\text { as well as their } \\
\text { feeling of nursing } \\
\text { burdens }>\end{array}$ & $\begin{array}{l}<\text { promotion of } \\
\text { expression of } \\
\text { family feelings } \\
\text { shaken by choice } \\
\text { of treatment place } \\
\text { after discharge> }\end{array}$ & $\begin{array}{l}\text { <expression of } \\
\text { thoughts related } \\
\text { to emergency } \\
\text { response of distant } \\
\text { families }>\end{array}$ & $\begin{array}{l}<\text { share patient and } \\
\text { family awareness } \\
\text { regarding aLs } \\
\text { acceptance }>\end{array}$ & $\begin{array}{l}<\text { clarification of } \\
\text { feelings of family } \\
\text { care burden } \\
\text { due to marital } \\
\text { relationship> }\end{array}$ & $\begin{array}{l}<\text { investigation } \\
\text { of the burden of } \\
\text { family care for aLs } \\
\text { patients }>\end{array}$ \\
\hline $\begin{array}{lr}<\text { extraction } & \text { of } \\
\text { multifaced issues } \\
\text { associated } \\
\text { patients' with } \\
\text { care self- } \\
\text { demonstration of } \\
\text { multidisciplinary } \\
\text { expertness> }\end{array}$ & $\begin{array}{l}<\text { request for family } \\
\text { guidance regarding } \\
\text { safe mobility } \\
\text { assistance r to } \\
\text { physical therapists> }\end{array}$ & 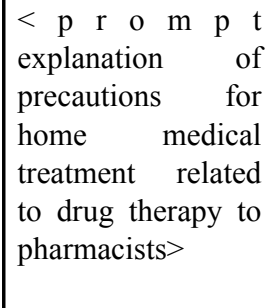 & $\begin{array}{l}<\text { cooperation with } \\
\text { the government } \\
\text { in home support } \\
\text { for } \quad \text { welfare } \\
\text { households> }\end{array}$ & $\begin{array}{l}<\text { sharing the flow } \\
\text { of home nurse } \\
\text { support during } \\
\text { visiting nurses }>\end{array}$ & \begin{tabular}{|lr}
$<$ p r o v i d i $\mathrm{n} g$ \\
information \\
patients & to \\
families & and \\
integrate & opinions \\
of & various \\
occupations $>$ &
\end{tabular} \\
\hline $\begin{array}{l}<\text { sharing of } \\
\text { patients' self- } \\
\text { m a n a g e m e n t } \\
\text { methods associated } \\
\text { with home-based } \\
\text { drug therapy> }\end{array}$ & $\begin{array}{lr}<\text { adjustment } & \text { of } \\
\text { discharge } & \text { guidance } \\
\text { regarding } & \text { family } \\
\text { medication } & \text { by } \\
\text { pharmacists } & \end{array}$ & \begin{tabular}{|lr}
$<$ p r o & m o t i n $g$ \\
oral & guidance \\
by & pharmacists \\
to & patients \\
with & diabetic \\
nephropathy $>$ &
\end{tabular} & $\begin{array}{l}<\text { support for } \\
\text { pharmacotherapy } \\
\text { for cancer pain to } \\
\text { improve quality of } \\
\text { life at home }>\end{array}$ & $\begin{array}{l}<\text { sharing of } \\
\text { explanations for } \\
\text { self-management } \\
\text { of pharmacists } \\
\text { taking medications } \\
\text { and medical drugs } \\
\text { at home }>\end{array}$ & \\
\hline \multirow[t]{2}{*}{$\begin{array}{l}\text { [sharing issues for } \\
\text { multidisciplinary } \\
\text { c ollaboration/ } \\
\text { cooperation along } \\
\text { with feelings } \\
\text { induced by } \\
\text { expression of } \\
\text { recognitions of } \\
\text { patients and their } \\
\text { families] }\end{array}$} & $\begin{array}{l}\text { [corresponding } \\
\text { to the family } \\
\text { a n t i c i p a t or y } \\
\text { anxiety of with } \\
\text { respect to a disease } \\
\text { state of the patient, } \\
\text { which became clear } \\
\text { in the effective } \\
\text { utilization of } \\
\text { nursing summary] }\end{array}$ & $\begin{array}{l}\text { [expression } \\
\text { recognition } \\
\text { decision making } \\
\text { regarding family } \\
\text { recup e r a t i o n } \\
\text { places] }\end{array}$ & $\begin{array}{l}\text { [representation } \\
\text { of awareness of } \\
\text { family care at home } \\
\text { and relaxation of } \\
\text { feelings] }\end{array}$ & $\begin{array}{l}\text { [sharing the weak } \\
\text { care-giving power } \\
\text { of families who } \\
\text { are confused by } \\
\text { the selection of key } \\
\text { persons as multi- } \\
\text { profession] }\end{array}$ & $\begin{array}{l}\text { [ i mprovement } \\
\text { of a dialogue } \\
\text { e n viron m e n t } \\
\text { connected to the } \\
\text { society of aLs } \\
\text { patients and close } \\
\text { support in line with } \\
\text { family support } \\
\text { needs] }\end{array}$ \\
\hline & $\begin{array}{l}{[\mathrm{s} h \text { a } \mathrm{r} \text { i } \mathrm{g}} \\
\mathrm{p} \text { e } \mathrm{r} \text { e e } \mathrm{pt} \text { i o } \mathrm{n} \mathrm{s} \\
\text { regarding inpatient } \\
\text { treatment for single } \\
\text { patients at patient- } \\
\text { p a r t i c i p a t i o n } \\
\text { conferences] }\end{array}$ & $\begin{array}{l}\text { [examination of } \\
\text { transportation } \\
\text { methods related } \\
\text { to outpatient } \\
\text { facilities in close } \\
\text { proximity to the } \\
\text { living conditions } \\
\text { of patients and } \\
\text { families] }\end{array}$ & 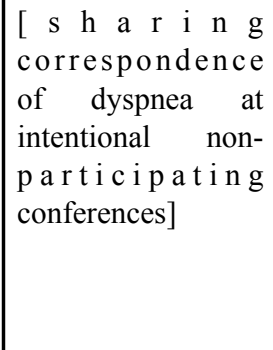 & $\begin{array}{l}\text { [setting goals for } \\
\text { improving living } \\
\text { at home with } \\
\text { patients based on } \\
\text { examination by } \\
\text { professionals for } \\
\text { welfare recipients } \\
\text { living alone] }\end{array}$ & $\begin{array}{l}\text { [share of } \\
\text { continuous nursing } \\
\text { of visiting nurses to } \\
\text { fulfill the wishes of } \\
\text { patients undergoing } \\
\text { cancer treatment] }\end{array}$ \\
\hline
\end{tabular}




\begin{tabular}{|c|c|c|c|c|c|}
\hline $\begin{array}{l}\text { <planning of the } \\
\text { home-based care } \\
\text { support for the } \\
\text { purpose of respite } \\
\text { care> }\end{array}$ & $\begin{array}{l}<\text { proposal on } \\
\text { respite care for } \\
\text { family caregivers }>\end{array}$ & $\begin{array}{l}<\text { proposal for } \\
\text { use of family } \\
\text { care insurance } \\
\text { service for respite } \\
\text { purposes }>\end{array}$ & $\begin{array}{l}\text { <promotion of the } \\
\text { use of long-term } \\
\text { care insurance } \\
\text { services intended } \\
\text { for family health } \\
\text { management and } \\
\text { respite care> }\end{array}$ & & \\
\hline $\begin{array}{l}<\text { planning and } \\
\text { assuring continuous } \\
\text { provision of patient } \\
\text { support through } \\
\text { collab or ations } \\
\text { among individuals } \\
\text { of the same } \\
\text { profession in } \\
\text { different divisions> }\end{array}$ & $\begin{array}{l}<\text { coordination } \\
\text { of drug and drug } \\
\text { collaboration } \\
\text { between hospital } \\
\text { and home } \\
\text { pharmacist> }\end{array}$ & $\begin{array}{l}<\text { promotion of } \\
\text { continuous nursing } \\
\text { by sharing nursing } \\
\text { problems between } \\
\text { ward nurses and } \\
\text { visiting nurses }>\end{array}$ & $\begin{array}{l}<\mathrm{p} \mathrm{r} \text { o m o t i o } \mathrm{n} \\
\text { of continuous } \\
\text { nursing by visiting } \\
\text { nurses under the } \\
\text { logistical support } \\
\text { of hospitals> }\end{array}$ & & \\
\hline $\begin{array}{l}\text { <encouragement } \\
\text { of multidisciplinary } \\
\text { participation } \\
\text { in professional } \\
\text { c o n f e r e } \mathrm{n} \mathrm{ces} \\
\text { s u p p o r t e d } \\
\text { by smooth } \\
\text { c o } 11 \text { a b o r a tion } \\
\text { among various } \\
\text { professionals inside } \\
\text { the hospital> }\end{array}$ & 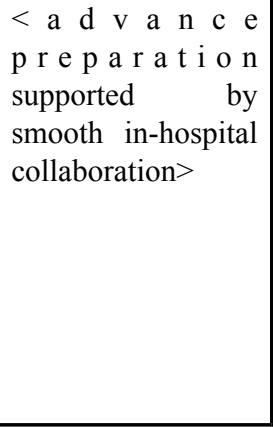 & $\begin{array}{l}<\text { understanding } \\
\text { difficult discharge } \\
\text { cases by } \\
\text { providing advance } \\
\text { information from } \\
\text { outpatient nurses> }\end{array}$ & $\begin{array}{l}<\text { promoting } \\
\text { participation } \\
\text { in various } \\
\text { occupations }>\end{array}$ & $\begin{array}{l}<\text { sharing concerns } \\
\text { about home } \\
\text { support by multiple } \\
\text { occupations }>\end{array}$ & $\begin{array}{l}<\mathrm{d} \text { e } \mathrm{v} \text { i } \mathrm{c} \text { e } \mathrm{s} \\
\text { that promote } \\
\text { p rofess i o n a l } \\
\text { collaboration }>\end{array}$ \\
\hline $\begin{array}{l}<\text { reinforcement } \\
\text { of their ability } \\
\text { to identify } \\
\text { characteristics } \\
\text { of patients as } \\
\text { local community } \\
\text { members }>\end{array}$ & $\begin{array}{l}\text { <promoting the } \\
\text { ability of ward } \\
\text { nurses to grasp } \\
\text { the characteristics } \\
\text { of patients as } \\
\text { c o m } \mathrm{m} \mathrm{n} \text { i t y } \\
\text { residents> }\end{array}$ & $\begin{array}{l}<\text { speaking of labor } \\
\text { to single patients }>\end{array}$ & $\begin{array}{l}<\mathrm{s} u \mathrm{p} \mathrm{p} \mathrm{o} \mathrm{rt} \\
\text { for building } \\
\mathrm{rel} \text { at i o } \mathrm{ships} \\
\text { of trust with } \\
\text { family medical } \\
\text { professionals }>\end{array}$ & & \\
\hline
\end{tabular}

The structure of discharge-planning nursing practice in transitional support toward home-based care, including the multidiscipline professional conferences, was revealed as below (Figure 1).

The discharge planning nurses had been trying to explain to the conference participants that the "level of planning" was 'complex' and the "degree of issues" was 'large' in the <initial management of care-service planning by sharing issues associated with home-based care services $>$.

For "degree of information provision" from the physician in charge or ward nurses to multidisciplinary professionals, the discharge planning nurses had recognized that it was 'large' and specific/ discrete according to the 'complexity' of the "level of home-based care needs" for patients and their families and had spent adequate time considering that it would be crucial to <clarify the home-based care needs $>$.

Intentional management in <extraction of multifaced issues associated with patients' self-care through demonstration of multidisciplinary expertness $>$ by the discharge planning nurses had led to $<$ detection of bewilderment in selection of care environment for families from complex patient/family backgrounds as well as their feeling of nursing burdens $>$ and <sharing of patients' selfmanagement methods associated with home-based drug therapy> as "complexity of home-based medical/nursing care needs", "complexity of family relationships" and "bewilderment in selection of care environment" were 'intense' according to perspectives from multidisciplinary positions.

The discharge planning nurses knew when exactly "the need for inducing expression of patients' and their families' recognitions" became 'high', while observing when provision of multidisciplinary information would be settled.

The discharge planning nurses had induced expression, namely verbalization, of recognitions of patients' and their families regarding transition toward home-based care, assuming that awareness of "necessity of sharing issues in multidisciplinary professional practice taking into consideration the feelings of patients and their families" would become 'high'.

In summary, the primary practice of discharge planning nurses was [sharing issues for multidisciplinary collaboration/cooperation along with feelings induced by expression of recognitions of patients and their families].

As a consequence of discharge-planning nursing care practice following this process, they had achieved a path to < planning of the home-based care support for the purpose of respite care $>$ so that the transition toward home-based care would be smooth for the patients and their families and had been < planning and assuring continuous provision of patient support through collaborations among individuals of the same profession in different divisions $>$ such as hospital pharmacists and local pharmacists as well as ward nurses and home-visit nurses.

Moreover, discharge planning nurses came to realize significance of <encouragement of multidisciplinary participation in professional conferences supported by smooth collaboration among various professionals inside the hospital>. 


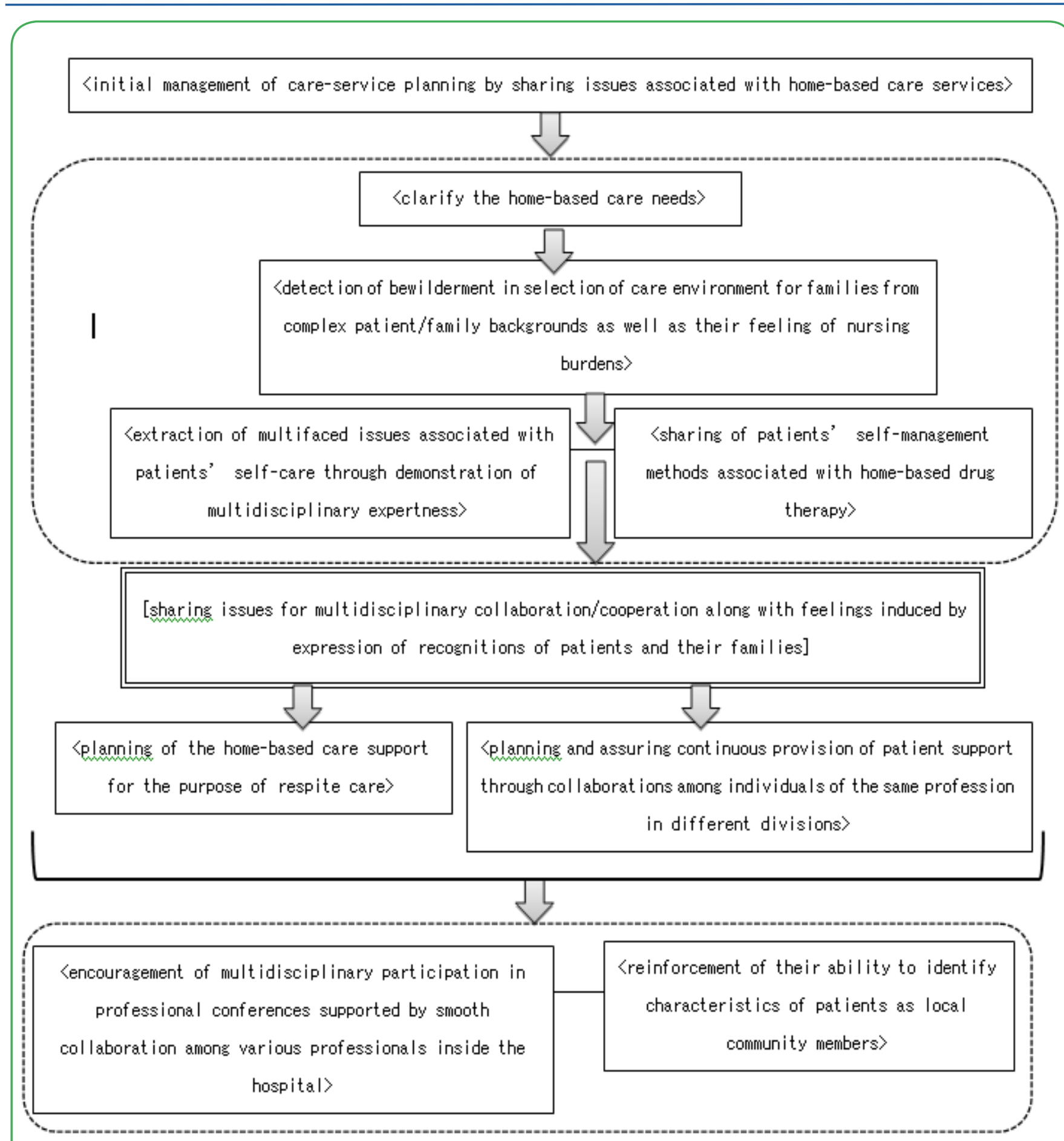

Figure. 1 The structure of discharge-planning nursing practice in transitional support toward home-based care, including the multidiscipline professional conference

In addition, they had attempted to contribute to the education of ward nurses through < reinforcement of their ability to identify characteristics of patients as local community members $>$ by providing opportunities to accumulate experiences of multidisciplinary collaboration in professional conferences.

\section{Discussion}

Compared to the nationwide survey (2014) conducted by Tomura, et al. 16), the mean age, the average number of years in nursing experiences, and the average number of years in dischargeplanning nursing experiences were about the same for the subjects, namely, discharge planning nurses who operated multidisciplinary professional conferences, suggesting that quality of data had been maintained.

Multidisciplinary professional conference in transitional support toward home-based care is a significant supportive activity connecting the hospital-based and home-based care. Hence, it is necessary for discharge planning nurses to improve nursing practice abilities so that multidisciplinary professionals will be able to feel that it is a significant opportunity for them to participate in the conferences.

The primary practice of discharge planning nurses in multidisciplinary professional conferences in this study was [sharing issues for multidisciplinary collaboration/cooperation along with feelings induced by expression of recognitions of patients and their families].

Upon introduction of a multidisciplinary professional conference, they should imagine the perspective of home-based care support as <initial management of care-service planning by sharing issues associated with home-based care services $>$ and notify the participants 
of this matter in the early stage of the conference so that they can imagine the situation from various positions of patients and their families as well as multidisciplinary professionals. This will clarify the directions of supports, making their roles clear and encouraging their motivations even more to participate in the conferences.

At the same time, discharge planning nurses attempt to <clarify the home-based care needs $>$ from multidisciplinary professionals including physicians in charge. Hence, it is crucial for them to predict situations and prepare themselves by taking into consideration the physicians' absence or leave in the middle of the meeting, understanding the treatment plan and choices in advance, asking a ward nurse to speak for the physician in charge, and helping the physician and multidisciplinary professionals to exchange information.

In order to clarify the needs of home-based care, it is essential for them to have certain perspectives for understanding the patients' selfcare abilities and preparing the patients and their families, namely the care givers who are affected by the patients, for their lives with home-based care as well as their social lives which may change along with healthcare services that they receive.

Hence, discharge planning nurses have been intentionally managing <extraction of multifaced issues associated with patients' self-care through demonstration of multidisciplinary expertness $>$. As a consequence, if the multidisciplinary professionals become aware of $<$ detection of bewilderment in selection of care environment for families from complex patient/family backgrounds as well as their feeling of nursing burdens $>$, they will be encouraged to make further assessments and exchange opinions based on their expert knowledge.

This suggests that, by integrating these opinions, it will be possible to extract problems and issues associated with transitional support toward home-based care in the early stage and to provide more individual-based planning of home-based care services.

It can be assumed that the discharge planning nurses who have gone through this practice process would be able to consider provision of family supports such as <planning of the home-based care support for the purpose of respite care $>$.

From the perspectives of family supports and care-givers' rest 17), the importance of using long-term care services covered by the health insurance, such as short-stay services as respite care, has been emphasized. Promotion of rest and health management of family care givers is directly associated with the quality of life for patients and their families. Therefore, active investigations on stress-coping strategies, etc. for family care-givers will be important in the future.

Meanwhile, <sharing of patients' self-management methods associated with home-based drug therapy $>$ by hospital pharmacists has been frequently observed, suggesting that it is important to coordinate provision of continuous supports through collaborations between hospital pharmacists and local pharmacists. 18) 19) As for $<$ planning and assuring continuous provision of patient support through collaborations among individuals of the same profession in different divisions $>$ such as hospital pharmacists and local pharmacists as well as ward nurses and home-visit nurses, it may be a privilege for the discharge planning nurses who are in the position of connecting the hospital and home-based care settings to understand the significance and issues associated with the collaborations among individuals of the same profession.

Multidisciplinary collaboration which enables the team to share the same directions in supports and to provide integrated care is crucial for transitional supports toward home-based care for the patients and their families. However, it is also important for the discharge planning nurses to choose appropriate professionals who can take over the supports while maintaining their specialties.

Moreover, contribution to formation of a hospital network, which will be the core for the discharge support system, as seen in the
$<$ encouragement of multidisciplinary participation in professional conferences supported by smooth collaboration among various professionals inside the hospital $>$ would be a foundation for practice of the discharge planning nurses from the perspective of maintaining high-quality discharge supports.

These practices of the discharge planning nurses may provide opportunities for the ward nurses to be educated through $<$ reinforcement of their ability to identify characteristics of patients as local community members $>$. This will improve their ability in discharge support, and the smooth collaboration among individuals of the same profession may provide a solid basis for transitional supports toward home-based care.

\section{Conclusion}

In multidisciplinary professional conferences, the discharge planning nurses intentionally performed <extraction of multifaced issues associated with patients' self-care through demonstration of multidisciplinary expertness $>$ and $<$ sharing of patients' selfmanagement methods associated with home-based drug therapy $>$ so that $<$ detection of bewilderment in selection of care environment for families from complex patient/family backgrounds as well as their feeling of nursing burdens $>$ will be possible for the multidisciplinary professionals to $<$ clarify the home-based care needs $>$ in the $<$ initial management of care-service planning by sharing issues associated with home-based care services $>$.

As a consequence of [sharing issues for multidisciplinary collaboration/cooperation along with feelings induced by expression of recognitions of patients and their families], the discharge planning nurses achieved a path to $<$ planning the home-based care support for the purpose of respite care $>$ and $<$ planning and assuring continuous provision of patient support through collaborations among individuals of the same profession in different divisions $>$. They had also recognized and conducted their roles in education of ward nurses through <encouragement of multidisciplinary participation in professional conferences supported by smooth collaboration among various professionals inside the hospital $>$ and <reinforcement of their ability to identify characteristics of patients as local community members $>$ based on reflections on their practices.

\section{Limitations of this study and future issues}

This study was conducted only in one hospital. Hence, it was not adequate to cover the entire system of practices of discharge planning nurses, including multidisciplinary professional conferences in the transitional supports toward home-based care, from various perspectives of local characteristics and hospital functions. It is necessary to investigate if this information can be useful in any other practices.

\section{Acknowledgments}

The author sincerely appreciates the patients discussed in the multidisciplinary professional conferences held at Hospital A and their families as well as discharge planning nurses and professionals for providing a precious opportunity for learning in the conduct of this study. She also would like to express her gratitude to the researchers who provided valuable advices in this qualitative study.

This article is a summary of a part of a doctoral dissertation.

\section{References}

1. Cabinet Office, Government of Japan. Annual Report on the Aging Society Japanese (2015).

2. Shirasawa M (2015) Heading towards establishment of integrated community care system in Japanese. Japanese journal of gerontology. 37: 28-35.

3. Ministry of Health, Labor and Welfare, Government of Japan. Medical fee revision (2016).

4. Japanese association of Welfare Statistics Association (2016) National Health Trends and Welfare Indicators 62: 11. 
5. Ministry of Health, Labor and Welfare, Government of Japan. Medical fee revision (2012).

6. Masayasu. M (2010) Japanese medical administration and community health policy, system history and basic knowledge Volume 2: Text for medical management specialist, First Grade, Medical management partner, Tokyo, Japan.

7. Yukiko. H (1998) Post-discharge care and utilization of social resources. Hospitals : 1096-1100.

8. Mayumi H, Satoko N, Hikari T, et al (2012) Agendas of Home Assistance for Medically Fragile Children : Discussion of Discharge Planning and Post-discharge Problems with Medically Fragile Children and Their Families. J Jpn Aca Comm Health Nurs 14: 32-42.

9. Kieko H, Masataka O, Kazuko U, et al (2009) Visiting nurses' nursing for end of life care in terminal patients, a transitional period from hospital to home care. J health care and Nurs5: 6974.

10. Kaori I (2011) The hospital experience of new-long-stay patients in the psychiatric ward, J Gifu College of Nurs 11: 13-24.

11. Makoto F (2012) Research on the Ways of Nursing for Improving the Quality of Discharge Support in Medical Institutions (Part 1) Clarify Discharge Support Issues in Medical Institutions to Tackle by Nurses. J Gifu College of Nurs 12: 57-65.

12. Shiho Y, Yasuko M (2016) Discharge Coordination Nurse's Involvement for improving practice ability of Ward Nurses: Focused on the Situation Recognition and Approach in Discharge Arrangement. Journal of Kochi Women's University Aca Nurs 41: 60-69.

13. Chihumi Y, Takako I, Yumi Chiba, et al (2012) Development of a Reflective Learning Program for Nurses to Support Patient Discharge. Bulletin of Chiba Prefectural University of Health Sci 3: 3-12.

14. Legrain S, Tubach F, Bonnet-Zamponi D, et al. (2011) A new multimodal geriatric discharge-planning intervention to prevent emergency visits and rehospitalizations of older adults the optimization of medication in AGEd multicenter randomized controlled trial. J Am Geriatrics Soc 59: 2017-2028.

15. Shyu YI, Chen MC, Chen ST, et al. (2008) A family caregiveroriented discharge planning program for older stroke patients and their family caregivers. J Clini Nurs 17: 2497-2508.

16. Wallis M, Hooper J, Kerr D, et al. (2009) Effectiveness of an advanced practice emergency nurse role in a minor injuries unit. Aus J Adv Nurs 27: 21-29.

17. Shyu YI1, Kuo LM, Chen MC, Chen ST. (2010) A clinical trial of an individualised intervention programme for family caregivers of older stroke victims in Taiwan. J Clini Nurs 19: 1675-1685.

18. Arbaje AI, Maron DD, Yu Q, et al. (2010) The geriatric floating interdisciplinary transition team. J Am Geriatrics Soc 58: 36470.

19. Soares, Marcelo M, Jacobs, Karen, Laugaland, Kristin, et al. Interventions to improve patient safety in transitional care - a review of the evidence. Work 41: 2915-2924.

20. Naylor M. D, Sochalski J. A. (2010). Scaling Up: Bringing the Transitional Care Model into the Mainstream. The Commonwealth Fund 103: 1-11.

21. Ministry of Health, Labor and Welfare, Government of Japan. Medical fee revision reward score table (2016).

22. Flick. Uwe (2007) Qualitative sozialforschung, Rowohlt Taschenbuch Verlag, Hamburg.
23. Hikari T, Satoko N, Ayano T, et al. (2017) Discharge Planning Nursing Practice at Japanese Hospitals - Comparison of Nationwide Survey Results for 2010 and 2014. J Jpn Aca Nurs Sci 37: 150-160.

24. Hiroshi O, Kiyoko O (1995) Necessity of Difference between Respite Care and Short stay care in Community-based Services for the Elderly. Aca bulletin of Nagano University 17: 28-39.

25. Hiroki S, Akiko M, Kazutoshi M, et al. (2014) Problems of Collaboration between Community and Hospital Pharmacists for Cancer Chemotherapy and Proposed Corrective Measures: KJ Method Based Identification and Planning Workshop. The Pharm Soc Jpn 134: 563-574.

26. Maki I, Kaori M, Hirohide T et al. (2013) Cooperation Between Hospital Pharmacy Department and Insurance Pharmacy in Outpatient Chemotherapy. J Jpn Assoc rural Med 61: 703-709. 